University of South Florida

DIGITAL COMMONS

Digital Commons @ University of

@ UNIVERSITY OF SOUTH FLORIDA

South Florida

Marine Science Faculty Publications

College of Marine Science

3-25-2019

\title{
The Coastal Ocean Circulation Influence on the 2018 West Florida Shelf $K$. brevis Red Tide Bloom
}

\author{
Robert H. Weisburg \\ University of South Florida, weisburg@usf.edu \\ Yonggang Liu \\ University of South Florida, yliu@mail.usf.edu \\ Chad Lembke \\ University of South Florida, clembke@usf.edu \\ Chuanmin M. Hu \\ University of South Florida, huc@usf.edu \\ Katherine Hubbard \\ Florida Fish and Wildlife Conservation Commission
}

See next page for additional authors

Follow this and additional works at: https://digitalcommons.usf.edu/msc_facpub

Part of the Marine Biology Commons

\section{Scholar Commons Citation \\ Weisburg, Robert H.; Liu, Yonggang; Lembke, Chad; Hu, Chuanmin M.; Hubbard, Katherine; and Garrett, Mathew, "The Coastal Ocean Circulation Influence on the 2018 West Florida Shelf $K$. brevis Red Tide Bloom" (2019). Marine Science Faculty Publications. 477. \\ https://digitalcommons.usf.edu/msc_facpub/477}

This Article is brought to you for free and open access by the College of Marine Science at Digital Commons @ University of South Florida. It has been accepted for inclusion in Marine Science Faculty Publications by an authorized administrator of Digital Commons @ University of South Florida. For more information, please contact digitalcommons@usf.edu. 


\section{Authors}

Robert H. Weisburg, Yonggang Liu, Chad Lembke, Chuanmin M. Hu, Katherine Hubbard, and Mathew Garrett 


\author{
RESEARCH ARTICLE \\ 10.1029/2018JC014887 \\ Key Points: \\ - The results support the hypothesis \\ that $K$. brevis red tides originate \\ offshore \\ - Manifestation along the shoreline as \\ a toxic bloom occurs via an \\ upwelling circulation \\ - The intensity of the 2018 west \\ Florida shelf red tide was due to a \\ new 2018 event adding on to a \\ lingering 2017 event
}

Correspondence to:

R. H. Weisberg,

weisberg@usf.edu

Citation:

Weisberg, R. H., Liu, Y., Lembke, C., Hu, C., Hubbard, K., \& Garrett, M. (2019). The coastal ocean circulation influence on the 2018 West Florida Shelf $K$. brevis red tide bloom. Journal of Geophysical Research: Oceans, 124 2501-2512. https://doi.org/10.1029/ 2018JC014887

Received 20 DEC 2018

Accepted 20 MAR 2019

Accepted article online 25 MAR 2019

Published online 9 APR 2019

(C)2019. American Geophysical Union. All Rights Reserved.

\section{The Coastal Ocean Circulation Influence on the 2018 West Florida Shelf $K$. brevis Red Tide Bloom}

\author{
Robert H. Weisberg ${ }^{1}$ (D), Yonggang Liu' ${ }^{1}$ iD, Chad Lembke ${ }^{1}$, Chuanmin Hu' ${ }^{1}$, \\ Katherine Hubbard ${ }^{2}$ iD, and Mathew Garrett ${ }^{2}$ \\ ${ }^{1}$ College of Marine Science, University of South Florida, St. Petersburg, FL, USA, ${ }^{2}$ Florida Fish and Wildlife Conservation \\ Commission-Fish and Wildlife Research Institute, St. Petersburg, FL, USA
}

\begin{abstract}
Blooms of the harmful alga, Karenia brevis on the west Florida continental shelf are thought to initiate offshore before manifesting as a nuisance along the coastline. Contributing to such blooms are a complex sequence of events occurring within oligotrophic waters, which in any given year may or may not be facilitated by the ocean circulation. Once initiation occurs, the delivery from the region of offshore origination to the region of coastline manifestation requires an upwelling circulation, whereby $K$. brevis cells are advected shoreward along the bottom. The $2018 \mathrm{~K}$. brevis bloom was particularly intense owing to cells from the preceding 2017 bloom being reinforced by a newly formed bloom in 2018, a year when the offshore conditions in spring through early summer were again favorable for bloom development. As an event response to determine the potential for new cells to be delivered to the shore, a glider was deployed from 24 August 2018 to 17 September 2018 with a track line designed to map water properties over the hypothesized initiation region. The coastal ocean circulation during the deployment interval was generally upwelling favorable, but the passage of Tropical Storm Gordon temporarily disrupted this flow, after which K. brevis appeared along the Florida Panhandle coast. Strong upwelling then reestablished and K. brevis was subsequently observed along Florida's east coast. We describe the glider deployment, the K. brevis observations, and we use a numerical circulation model to account for the $K$. brevis manifestation as occurred along Florida's west, Panhandle, and east coasts.
\end{abstract}

Plain Language Summary We account for the intensity and location of the 2018 Karenia brevis red tide outbreak on the west Florida continental shelf by a combination of water property observations and numerical circulation model simulations. These confirm the initiation region being offshore, the manifestation region being along the shoreline and the delivery mechanism (from initiation to manifestation) being an upwelling favorable coastal ocean circulation. The intensity is attributed to the cells remaining in the manifestation region from the prior 2017 bloom being reinforced by cells newly formed offshore in 2018.

\section{Introduction}

The west coast of Florida experiences blooms of the harmful alga, Karenia brevis, a dinoflagellate whose toxins cause human respiratory distress, kill fish and other sea life, and disrupt the economies of the coastal regions where $K$. brevis blooms manifest. Not all years are subject to similar concentrations nor durations of $K$. brevis red tides. For a canonical red tide year, the expectation is for an onset in late summer to early fall, with concentrations diminishing into winter.

The years 1999, 2000, and 2001 behaved in this canonical manner, but most years behave much more randomly. For instance, 2010 experienced virtually no red tide from the spring season onward, 2011 and 2012 had substantial K. brevis cell concentrations, whereas 2013 showed only a very short-lived event. From 2014 onward, $K$. brevis blooms have occurred in each of these subsequent years. It is now fair to say that 2018 bloom (or the extended bloom that occurred from September 2017 to January 2019) was the worst of the red tide events since 2005, when high cell concentrations lasted from winter through summer until Hurricane Katrina ushered the beginning of its demise.

The epicenter for Florida red tide bloom manifestation (Figure 1) is the shoreline region between the Tampa Bay and Charlotte Harbor estuaries, although blooms often show up on the Panhandle coast and in some years they even appear on Florida's east coast and as far north as the Carolinas. The 2018 bloom is one for which $K$. brevis appeared within the epicenter region, the Panhandle, and the east coast. 


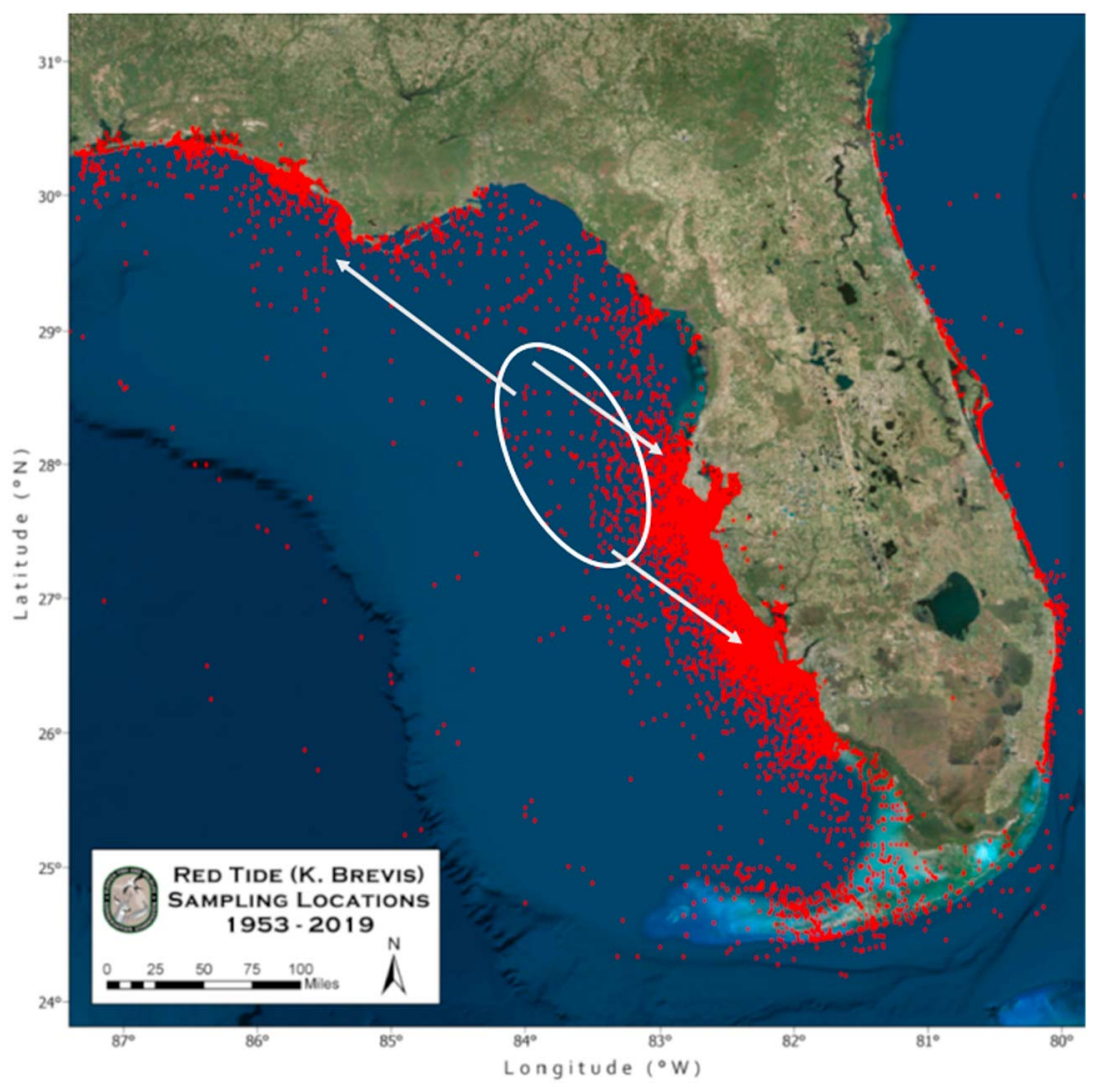

Figure 1. A composite of all observations of Karenia brevis made by the Florida Wildlife Research Institute from 1953 through 2007. Note the epicenter region from just north of the Tampa Bay to just south of Charlotte Harbor estuaries. The ellipse denotes the hypothesized, midshelf initiation region, and the arrows denote the transport pathways between initiation and manifestation within the epicenter region and along the Florida Panhandle.

Following a hypothesis on bloom generation, we recently mounted a glider deployment to sample water properties over the region thought to be the formative one for Florida red tide and spanning the latitudinal extent from which such red tide cells would be transported from the formative region offshore to the manifestation epicenter region alone the shoreline. The deployment interval (24 August 2018 to 17 September 2018) was at a time when the West Florida Continental Shelf (WFS) was under a state of upwelling, induced by the Gulf of Mexico Loop Current interacting with the shelf slope near the Dry Tortugas. The passage of Tropical Storm Gordon temporarily disrupted this circulation about 1 week into the deployment, after which the circulation returned to its upwelling favorable state. This deployment also coincided with the spatially extensive southwest Florida K. brevis bloom that was first observed within the Charlotte Harbor region in fall 2017, presenting an opportunity to investigate the potential for bloom intensification over the epicenter region at the time when new initiation typically occurs. The deployment also spanned the time frame when K. brevis concentrations first appeared along Florida's Panhandle coast and subsequently along Florida's east coast.

The present paper describes the water properties observed during the glider deployment and applies a Lagrangian particle trajectory analysis to account for the distribution of $K$. brevis as observed across the west Florida epicenter region, along Florida's Panhandle coast and along Florida's east coast. Section 2 provides the appropriate background information, section 3 describes the observations, section 4 discusses the trajectories, and section 5 summarizes and makes recommendations for improving $K$. brevis forecasting.

\section{Background}

Prior to 1998, it was postulated that blooms of Gymnodinium breve, identified as the organism responsible for WFS red tide blooms, were initiated some distance offshore (Steidinger, 1975) before appearing in medium 
$\left(10^{5}-10^{6}\right.$ cells per liter) to high $\left(>10^{6}\right.$ cells per liter) concentrations nearshore in late summer to early fall, primarily between the Tampa Bay and Charlotte Harbor estuaries. Interdisciplinary studies coincident with anomalous upwelling conditions of 1998 led to a fuller understanding of the biological and physical connections responsible for such blooms. Two companion papers (Walsh et al., 2003; Weisberg \& He, 2003) explained some of these. The first showed that anomalous upwelling carried cold, deeper ocean water across the shelf break and to the nearshore within the bottom Ekman layer. By examining historical temperature/nutrient correspondences, it was further noted that these upwelled, deeper ocean waters ventilated the WFS with new inorganic nutrients. The second showed how the new inorganic nutrients were consumed across the WFS, thereby favoring faster-growing phytoplankton (e.g., diatoms) over dinoflagellates and inhibiting the occurrence of a major $K$. brevis bloom in that year (we note that Gymnodinium breve was renamed Karenia brevis in 2001 in honor of the pioneering work by Dr. Karen Steidinger).

The biology of $K$. brevis is in itself quite complex. How is it possible for a slow growing dinoflagellate to outcompete faster growing diatoms? This was hypothesized (Walsh et al., 2006) to occur via a complex sequence of events, with the nitrogen fixing cyanobacterium Trichodesmium (helped through iron fertilization by Saharan dust, Lenes et al., 2001) feeding K. brevis offshore, where the lack of dissolved silicate precluded diatom dominance. Once established as a monospecific bloom, $K$. brevis is capable of using diverse sources to satisfy continued nutrient requirements, including the use of toxins to kill fish (e.g., Heil et al., 2014; Walsh et al., 2009). Thus, an established K. brevis bloom is difficult to extinguish. If transported to the coastline via upwelling, the bloom can then utilize riverine color dissolved organic matter for shading and gain additional nutrient support from terrestrial or oceanic sources (e.g., Hu et al., 2006; Vargo et al., 2008), continuing in a bloom state for months. Additional information on the biology of $K$. brevis are available in two special harmful algal bloom (HAB) issues, one by Walsh and Kirkpatrick (2008) and another by O'Neil and Heil (2014), and the utilization of satellite ocean color information for characterizing bloom evolution is discussed by Soto et al. (2018).

The $K$. brevis bloom of 2005 was among the most severe events recorded. The bloom onset was offshore, and the pathway to the coast was the bottom Ekman layer as demonstrated through model simulation/observation comparisons (Weisberg et al., 2009). These results provided further explanation on why $K$. brevis blooms on the WFS manifest between Tampa Bay and Charlotte Harbor, that is, the primary destination following the upwelling transport pathway to the coastline.

Regardless of the biological complexity, it is now clear that the ocean circulation physics play an important role in $K$. brevis ecology because the circulation is what determines whether or not the water properties are conducive for the biological complexity to function effectively. For instance, no red tide was observed on the WFS in 2010 owing to the anomalously strong and protracted upwelling that occurred in 2010 (Weisberg, Zheng, Liu, et al., 2014). What Weisberg and He (2003) and Walsh et al. (2003) jointly discussed for 1998 occurred again in 2010, and given improved modeling tools (Zheng \& Weisberg, 2012), we were able to make the case for why no bloom occurred. With these concepts established, compelling arguments were offered for why the K. brevis bloom of 2012 was robust, whereas the one in 2013 was relatively nominal and short lived (Weisberg, Zheng, Liu, Corcoran, et al., 2016). These coastal ocean circulation arguments were then employed successfully (albeit unpublished) to predict the 2014 and 2015 K. brevis blooms. Seeking a more formal method for seasonal prediction Liu et al. (2016) implemented a neural network analysis, combining satellite altimetry data with historical K. brevis cell counts for the period 1993-2015. To date, this approach accounted for either the occurrence or lack of occurrence of major K. brevis blooms for 20 of the past 25 years.

Whereas the region from Tampa Bay to Charlotte Harbor appears to be the epicenter for K. brevis HABs on the WFS, there are instances when we see blooms along Florida's Panhandle coast and even along Florida's east coast. Both the Panhandle and east coast blooms may share their origin with the epicenter region blooms. A period of northward advection can transport cells from the northern portion of the initiation zone to the Panhandle coast, and a period of protracted upwelling can transport cells around the Florida Keys and into the Gulf Stream. Once in the Gulf Stream, these cells can arrive at the east coast within a very short time duration (only a few days to Palm Beach and only a week or two to the Carolinas). Examples of Florida Panhandle blooms, also with a bottom Ekman layer delivery to the nearshore, are given by Kamykowski et al. (2013) and McCulloch et al. (2013), and an example of a Florida east coast bloom, emanating from 


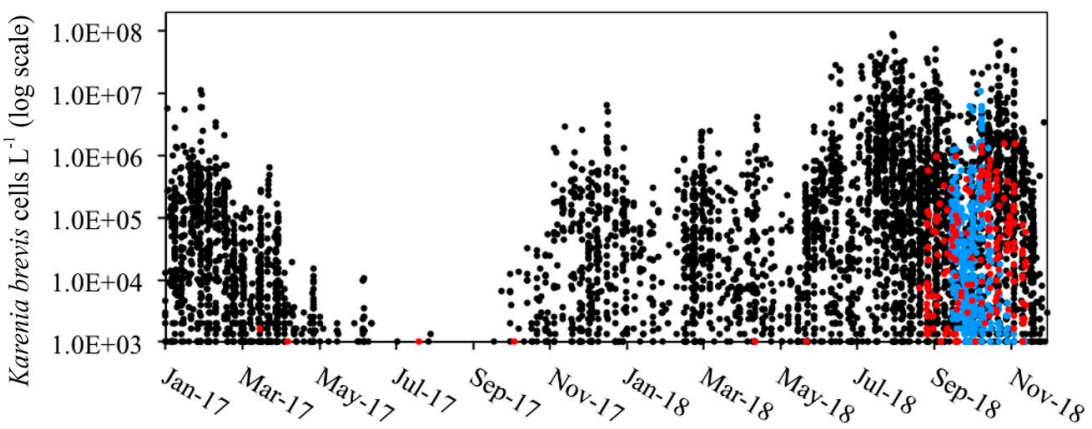

Figure 2. K. brevis cell counts plotted using log scale from 1 January 2017 through 16 December 2018 (from Florida Fish and Wildlife Conservation Commission - Fish and Wildlife Research Institute HAB monitoring database) show the persistence of the K. brevis bloom from 2017 through the spring and early summer of 2018 in the epicenter region (black circles), and the initiation of bloom conditions in the Panhandle (red) and on the east coast (blue). Only samples with $\geq 10^{3}$ cells per liter are shown (data source: Florida Fish and Wildlife Conservation Commission - Fish and Wildlife Research Institute HAB monitoring database).

the WFS epicenter region, and traveling around the Florida Keys to as far north as the Carolinas, is given by Walsh et al. (2009).

\section{Observations}

With the exception of 2013, major WFS K. brevis blooms (sustained concentrations exceeding $10^{6}$ cells per liter) have occurred annually since 2011. The 2017 bloom started in late summer/fall as anticipated, but for reasons not understood, it persisted throughout the winter and subsequent spring (Figure 2). With the Loop Current penetrating well into the Gulf of Mexico and distant from the Dry Tortugas region during the spring and early summer months of 2018, it was surmised (based on Liu et al., 2016) that 2018 would also experience a major $K$. brevis bloom, perhaps rivaling that of 2005 because whatever grew anew for 2018 would be additive to what was already in place from 2017.

To explore this possibility, we mounted the deployment of a profiling underwater glider, hereafter simply referred to as a glider. Gliders profile the water column from surface to near bottom for weeks at a time, traversing $100 \mathrm{~s}$ of $\mathrm{km}$ (Rudnick et al., 2004). With a suite of sensors, they sample water column variables and transmit these data back to the user several times per day. University of South Florida's Teledyne Webb Research Slocum glider was deployed from 24 August 2018 to 17 September 2018, with the intent of mapping the region offshore from which it was thought that new cells would be transported to the nearshore epicenter region. The deployment started at about the $25-\mathrm{m}$ isobath with a track line planned to zigzag from the initial position just to the north of Tampa Bay southward to the latitude of Sarasota, Florida. Figure 3 shows the glider track, which deviated somewhat from the original plan owing to the passage of Tropical Storm Gordon on 4 September 2018.

Prior to the glider deployment, the Loop Current shed an eddy in mid-July and retreated back to its more direct inflow (through the Yucatan Strait) to outflow (through the Straits of Florida) route, which placed it in contact with the Dry Tortugas region "pressure point." While this contact came too late in the summer to suppress a new $2018 \mathrm{~K}$. brevis bloom, its effect by setting the WFS in an upwelling circulation state ensured that whatever was blooming along the bottom offshore would eventually appear along the coast. This upwelling effect was observed throughout the month of September 2018, as shown in the Figure 4 composite of $K$. brevis cell concentrations. What was previously observed to the south of Tampa Bay and in particular to the south of Venice as holdovers from the 2017 bloom came into full effect over the entire epicenter region. Moreover, high cell concentrations also appeared along the Panhandle coast after Tropical Storm Gordon in early September and then on Florida's east coast toward the end of September (Figure 3).

The glider sampled temperature, salinity, chlorophyll, and dissolved oxygen, for which transect plots are provided in Figure 5. The low temperatures and higher salinities observed at depth are a reflection of the cooler, saltier waters transported across the shelf within the lower portion of the water column by the upwelling circulation. The highest values of chlorophyll are also observed near the bottom along with the lowest values for dissolved oxygen. While increased chlorophyll values are not uncommon at depth, here it is noted 


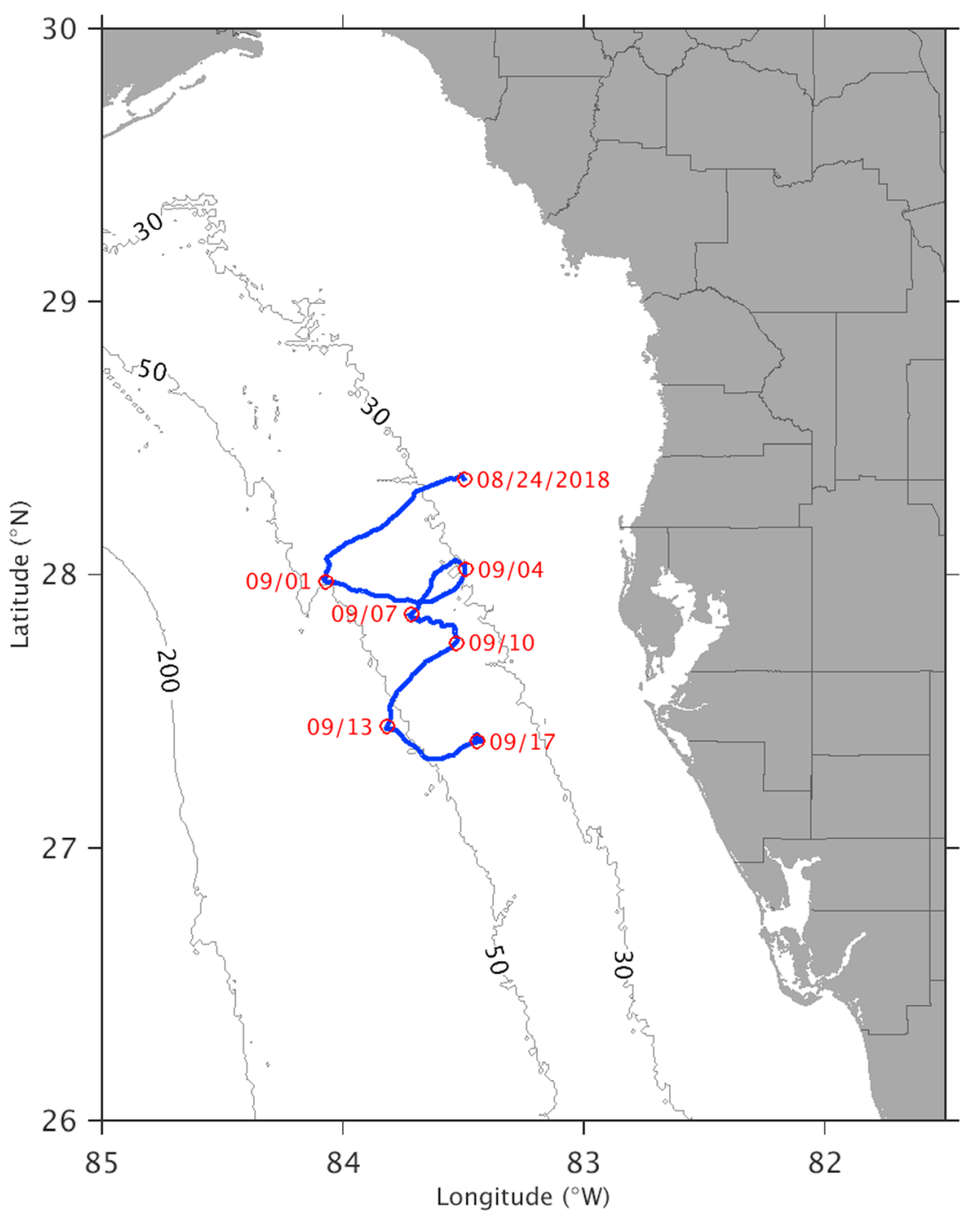

Figure 3. The glider mission track from 24 August 2018 to 17 September 2018. The loop observed around 4 September is attributed to tropical storm Gordon whose resulting northward currents were too strong for the glider to compete against.

that the highest values do not appear to be contiguous with the deeper ocean; instead these values are roughly centered between the 30- and 40-m isobaths, that is, they appear to be of midshelf origin. Where the chlorophyll is high, the oxygen tends to be low, indicative of respiration and/or the oxidation of decaying organic matter. While these factors alone do not confirm a $K$. brevis origin, a limited number of water samples taken during the deployment confirm their $K$. brevis nature, and while these limited samples are insufficient for a detailed calibration determination, they do suggest that the glider was observing concentrations in excess of $10^{4}$ cells per liter. Also of interest are the diurnal variations in dissolved oxygen with highest values in daytime and the diurnal variations in chlorophyll indicative of vertical migration with cells leaving the bottom during hours of darkness (e.g., Heil, 1986; Hu et al., 2016).

\section{Interpretations}

The observation of near-bottom chlorophyll maxima, later identified through microscopy as associated with $K$. brevis (at least for the limited number of water samples that were obtained) support the hypothesis of the $K$. brevis formative region being at midshelf and displaced northward from the manifestation epicenter region located primarily between the Tampa Bay and Charlotte Harbor estuaries. Based on the circulation being the delivery mechanism from formation to manifestation, can we account for the composite of September 2018 K. brevis observations shown in Figure 3? To answer this question we employ the West 


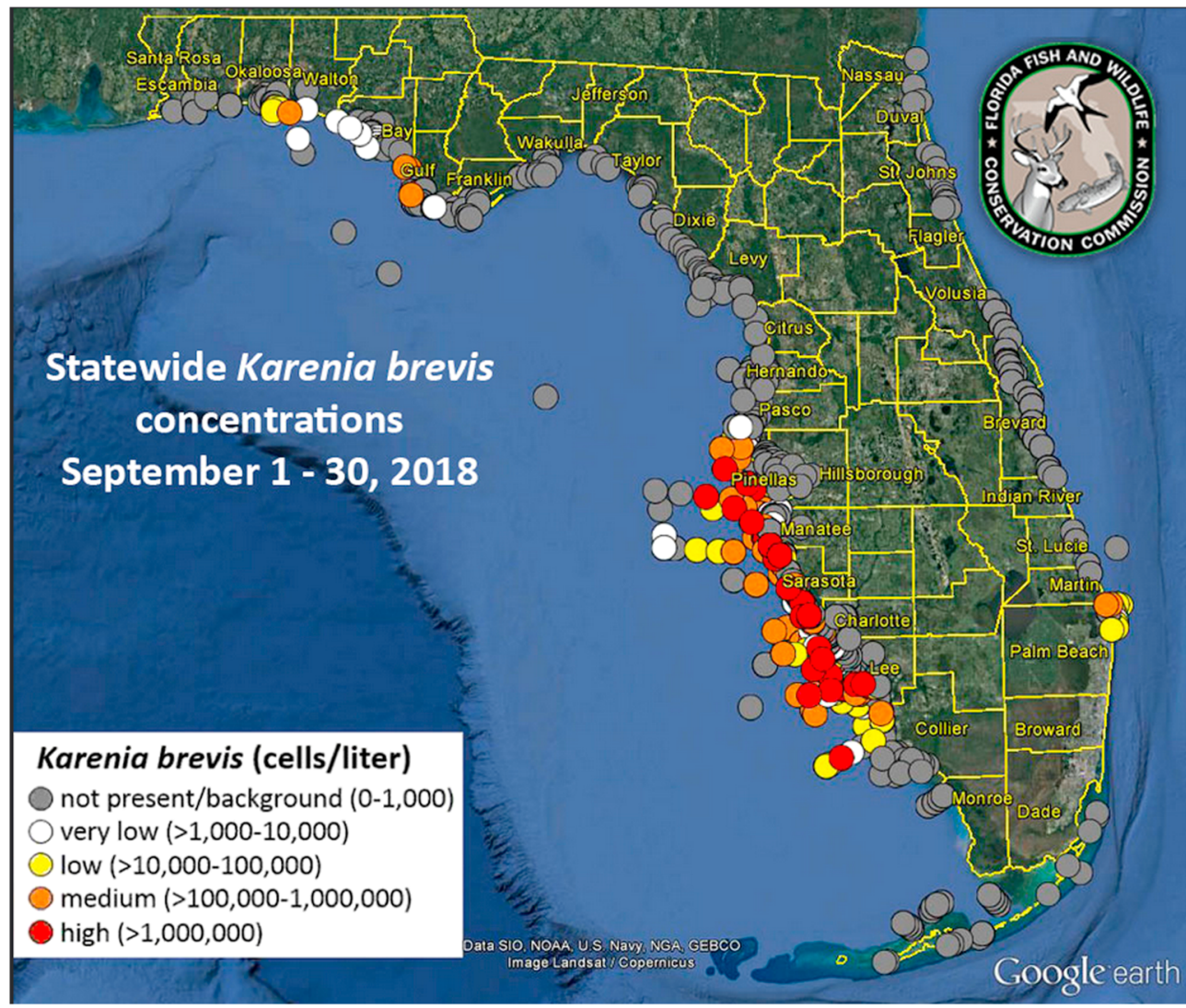

Figure 4. K. brevis cell count composite for the month of September 2018.

Florida Coastal Ocean Model (WFCOM), which consists of the unstructured grid, Finite Volume Community Ocean Model (FVCOM, e.g., Chen et al., 2003) nested in the Gulf of Mexico Hybrid Coordinate Ocean Model (GOM-HYCOM, e.g., Chassignet et al., 2009). FVCOM, as an unstructured grid model with flooding and drying, affords very high resolution and accommodates both realistic coastlines and shallow water depths. Thus, it allows for inclusion of the estuaries and Florida Bay, along with the inlets connecting these with the Gulf of Mexico and across the Florida Keys to the Straits of Florida. GOMHYCOM, as a data assimilative, structured grid model inclusive of tides, facilitates the inclusion of deeper ocean forcing for the WFS. By nesting FVCOM in GOM-HYCOM, we downscale from the deep ocean, across the continental shelf and into the estuaries. Zheng and Weisberg (2012) provided a WFCOM proof of concept, and subsequent applications include gag grouper recruitment (Weisberg, Zheng \& Peebles, 2014), K. brevis red tide (Weisberg, Zheng, Liu, et al., 2014; Weisberg, Zheng, Liu, Corcoran, et al., 2016) and tracking of the Deepwater Horizon oil spill (Weisberg, Zheng, Liu, Murawski, et al., 2016; Weisberg et al., 2017).

WFCOM presently provides daily, automated nowcasts and forecasts for the coastal ocean circulation from west of the Mississippi River to south of the Florida Keys. These also include short-term (4.5-day) hindcast/forecasts of $K$. brevis locations initialized with observations provided by the Florida Fish and Wildlife Conservation Commission-Fish and Wildlife Research Institute as a product of our Collaboration on the Prediction of Red tide. Here we employ WFCOM in hindcast to determine if we can account for the Figure 4 observations. Lagrangian trajectories are calculated using the isopycnic particle trajectory formalism of Weisberg, Zheng, and Liu (2016) that constrains particles to follow surfaces of constant potential density. The isopycnic Lagrangian calculations are performed off-line using hourly averages saved from the Eulerian WFCOM run. Thus, while mixing may alter the density field throughout the simulation, for each of the Lagrangian (hourly) time steps, the kinematic constraint of no flow across isopycnals is adhered to.

Results for particles initialized at the near-bottom level $(\sigma=-0.9)$ at locations and times coinciding with the glider deployment are shown in Figure 6. Recall that the glider deployment goal was to map out the 

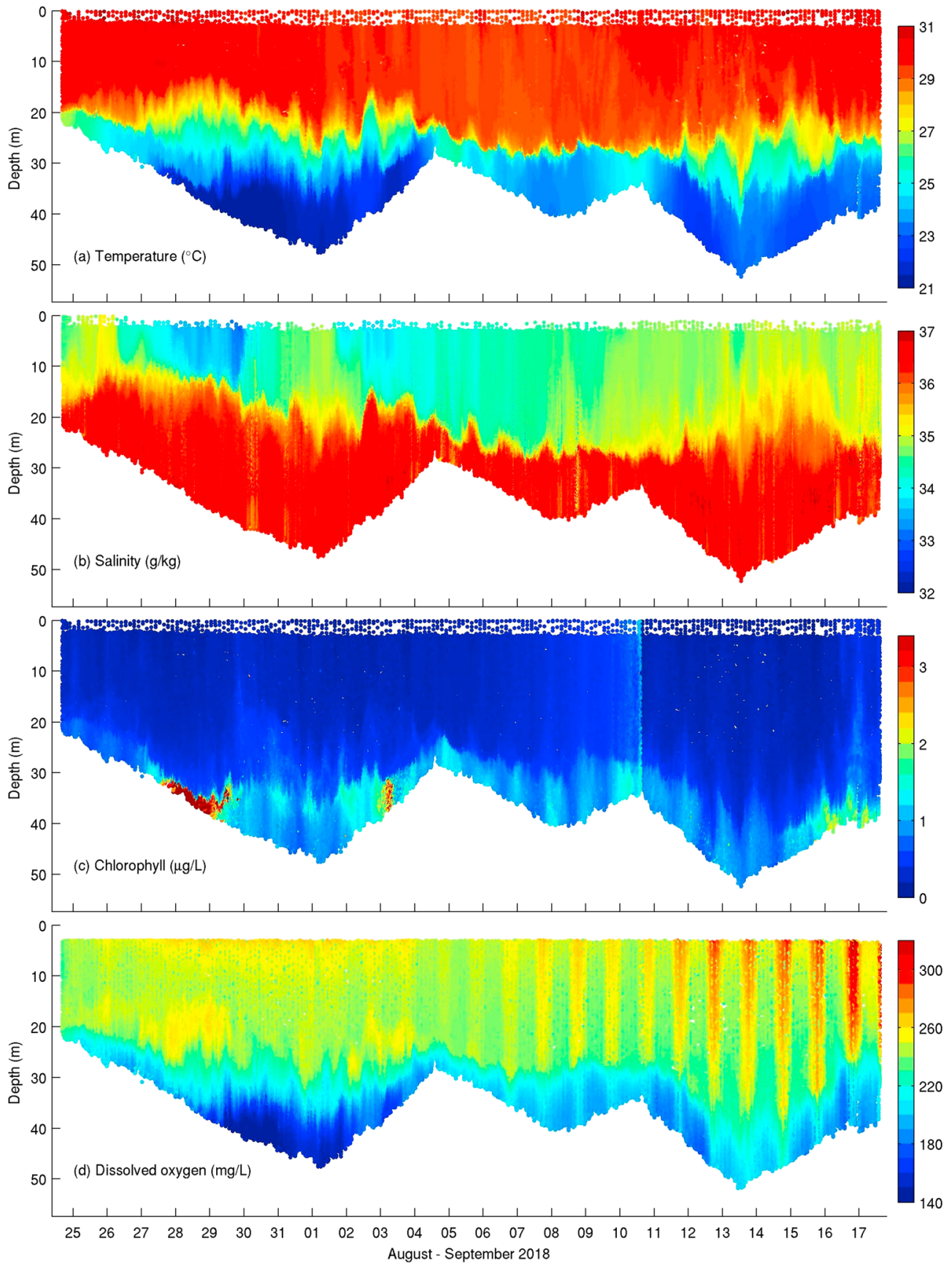

Figure 5. From top to bottom are temperature, salinity, chlorophyll, and dissolved oxygen, as observed along the glider track from 24 August 2018 to 17 September 2018. Note that (1) the salinity was corrected for the conductivity sensor time constant using the procedure provided by Liu et al. (2015) and (2) the line on 10 September coincides with a cleaning of the chlorophyll optics.

hypothesized $K$. brevis formative region from which $K$. brevis cells might be advected to the manifestation epicenter region along the shoreline. Based on the circulation over the diagnosed time interval, the hypothesis on transport from initiation to manifestation is demonstrated to be correct.

As a second hypothesis test, we may ask whether or not cells from the hypothesized formative region could have reached the Florida Panhandle coast. Whereas the protracted upwelling conditions continued along the bottom in the model simulation, the surface currents did reverse for several days beginning prior to the passage of Tropical Storm Gordon, and with vertical migration, it is plausible that cell concentrations 


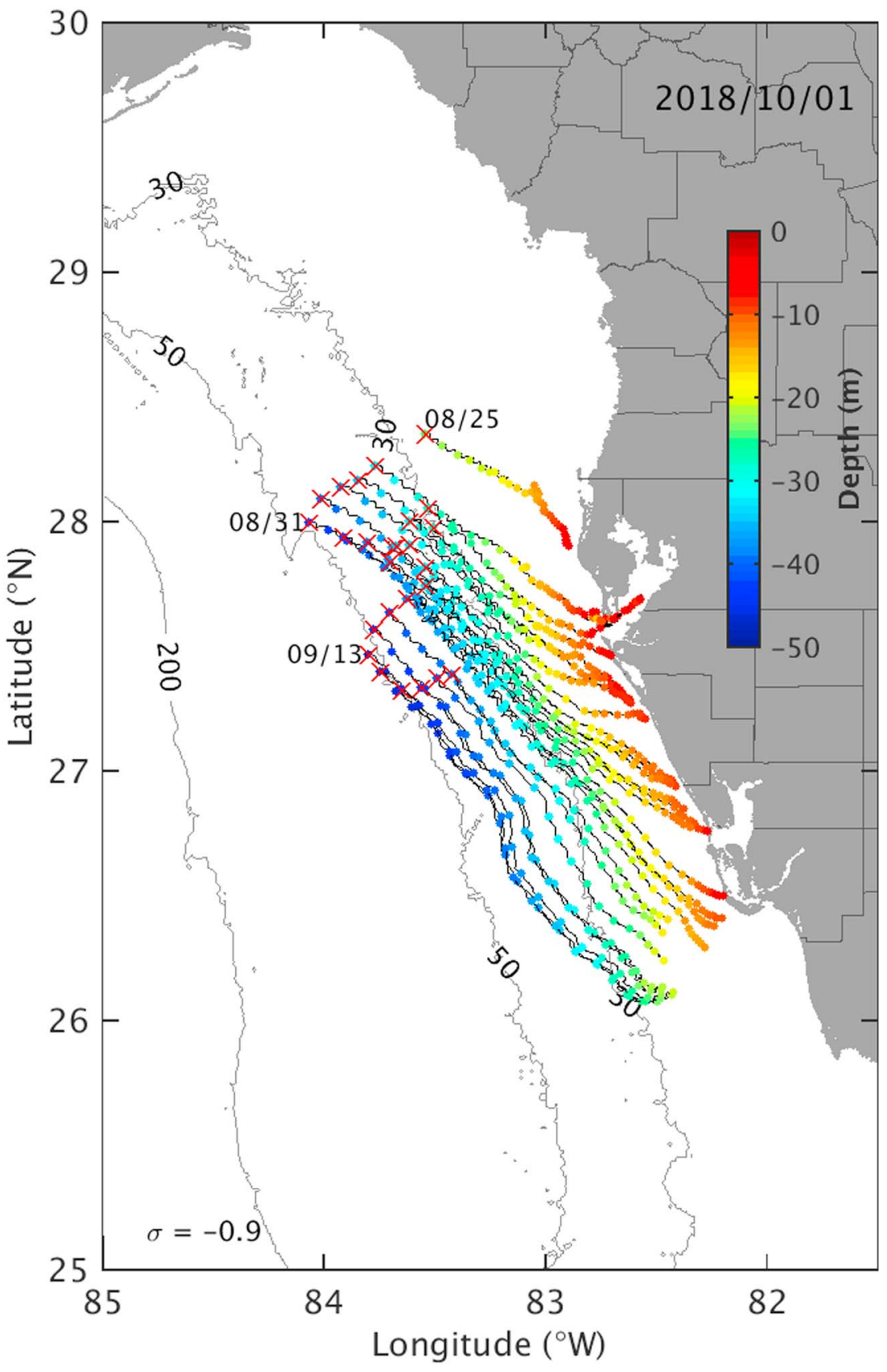

Figure 6. Isopycnic trajectories for particles initialized along the glider track from 24 August 2018 to 17 September 2018 and run through 1 October 2018, a total of 2 to 5 weeks. The initial vertical location for all of these particles was the nearbottom $(\sigma=-0.9)$ level, and the daily color coding provides the actual depth en route.

of lower magnitude may have occurred throughout the water column. Assuming this to be correct, Figure 7 demonstrates that cells migrating to the surface could have been advected to the Panhandle over the period associated with Tropical Storm Gordon, assuming that the formative region extended somewhat farther north than that covered by the glider deployment.

As a final hypothesis test, we may ask if the bloom subsequently seen on Florida's east coast could also have arrived from the formative region. Two scenarios are possible. The first assumes a direct pathway from the formative region to the east coast; the second assumes an indirect path such that particles first arrived at the manifestation epicenter region, later to be transported both offshore and around the Florida Keys. Both scenarios are plausible. While not shown, particle tracking results similar to Figure 6, but for cells initialized at 

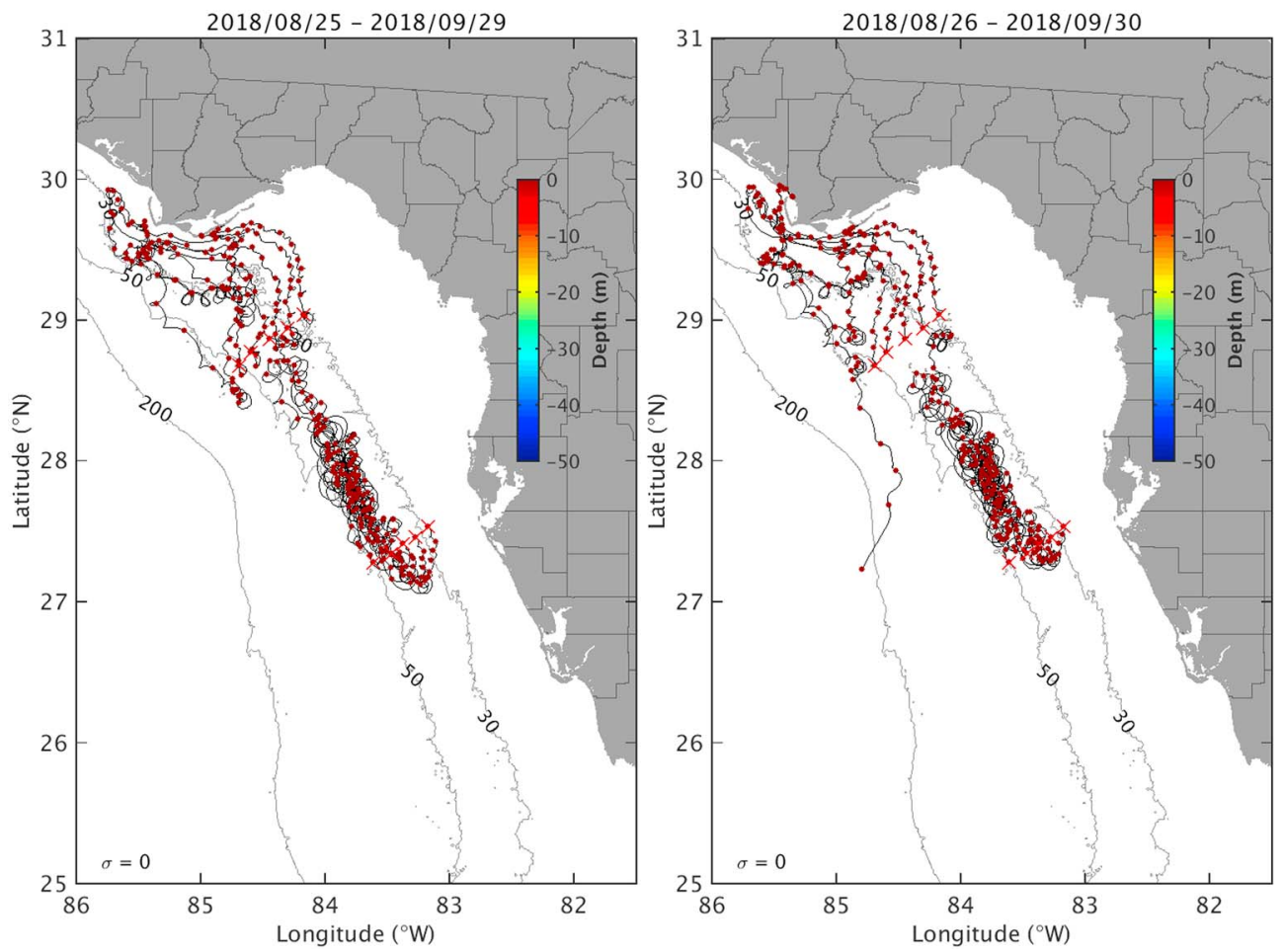

Figure 7. Isopycnic trajectories for particles initialized at the surface layer on 25 August 2018 (left-hand panel) or 26 August 2018 (right-hand panel) and tracked through the end of September. Only those particles released across the northern portion of the Big Bend region made it to the Panhandle.
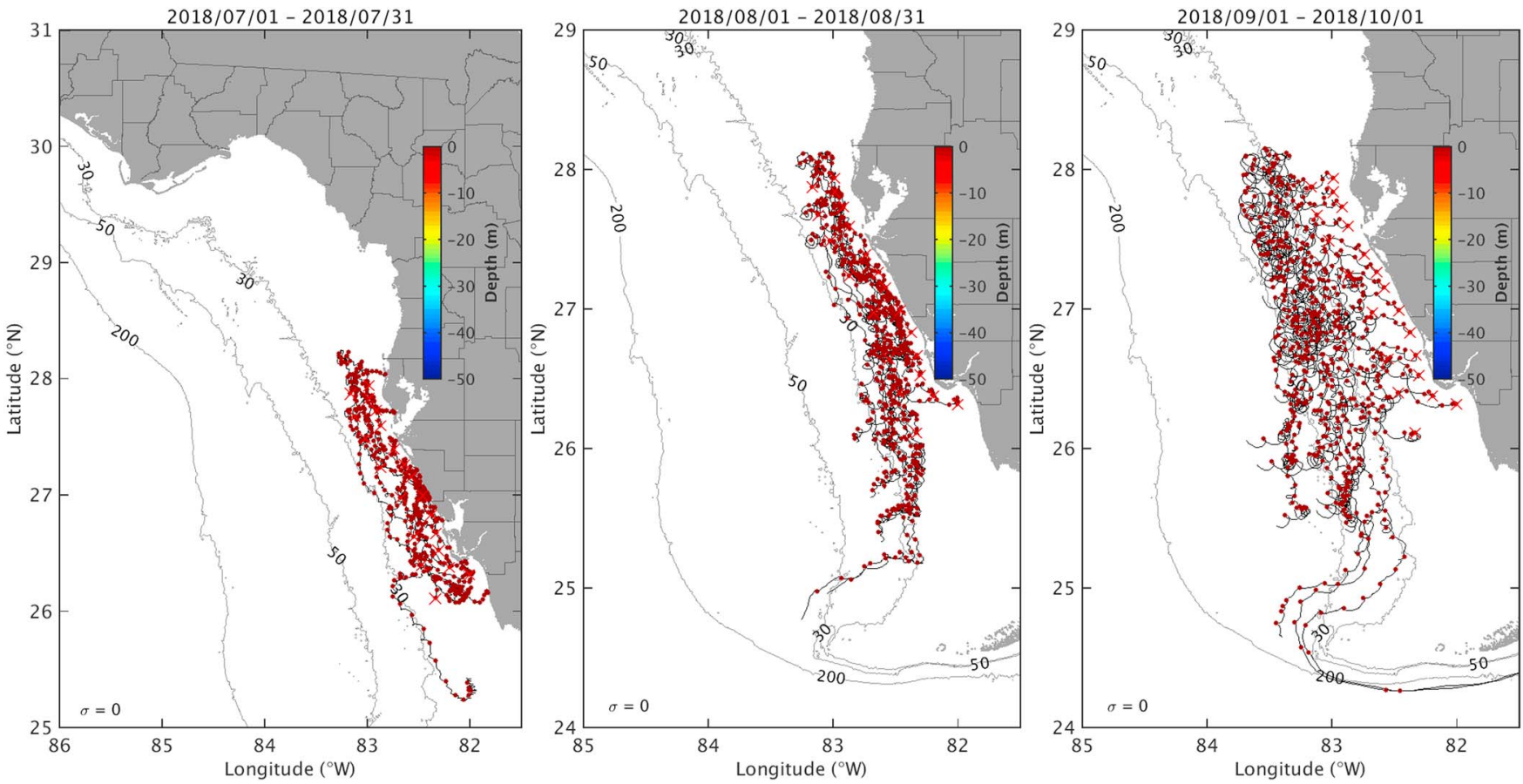

Figure 8. Isopycnic trajectories for particles initialized at the surface layer and tracked for 1 month. From left to right are initializations beginning on $1 \mathrm{July} 2018,1$ August 2018, and 1 September 2018, the latter being the most plausible of these. 

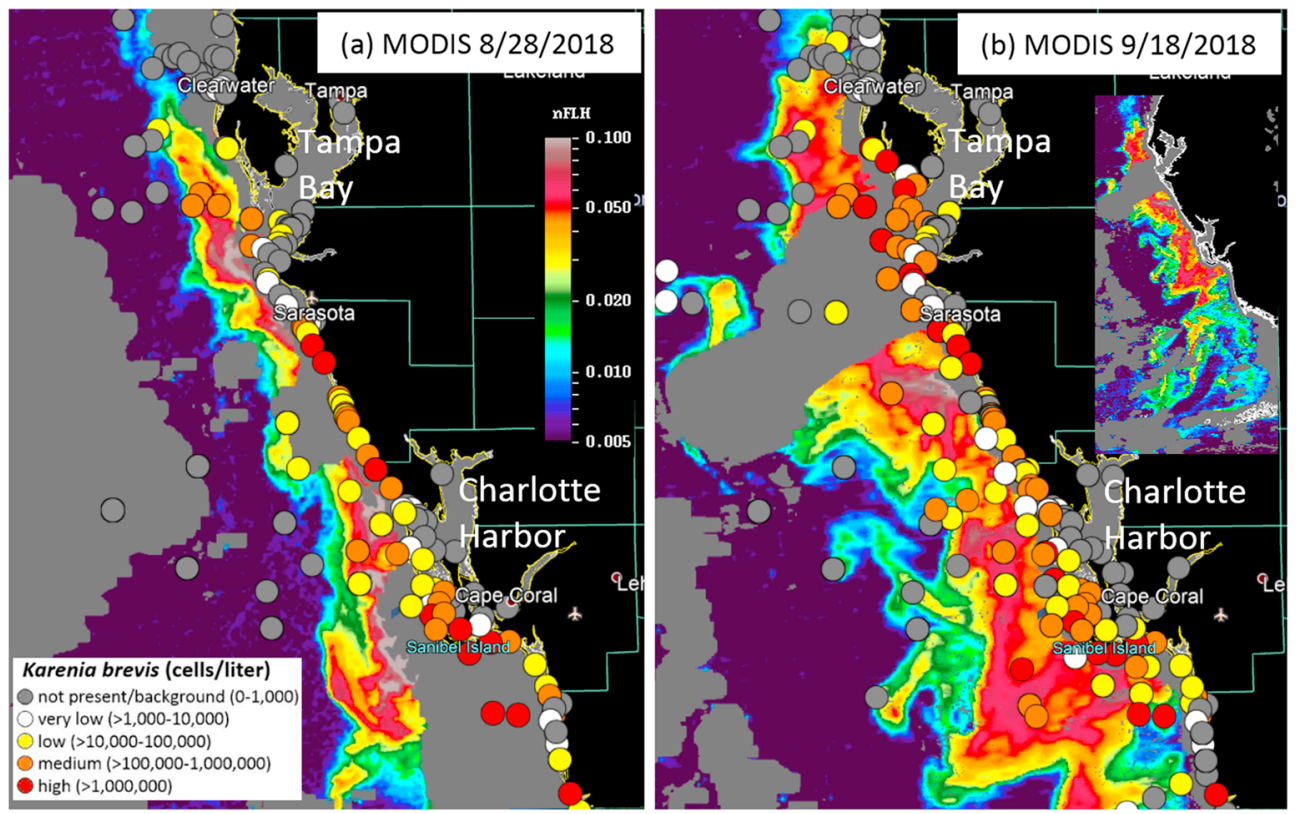

Figure 9. Modified Moderate Resolution Imaging Spectroradiometer (MODIS) fluorescence line height (or algal bloom index, Hu \& Feng, 2016) images collected on 28 August 2018 (a) and 18 September 2018 (b) showing K. brevis extending over the bloom manifestation region. Overlaid are K. brevis concentrations (cells per liter) determined by FWRI using water samples collected during the same week of the MODIS image collection, which confirmed that ABI values of $>0.02$ correspond to $>10^{3}$ cells per liter of $K$. brevis. Note the increase in offshore extent on 18 September relative to 28 August owing to strong easterly winds. The inset in (b) is the same image on 18 September but with coverage further to the south showing the surface transport of $K$. brevis cells to the Florida Keys, consistent with the model simulation results in Figure 8c.

midwater column, versus the near-bottom, exhibited advection to the Florida Keys. Figure 8 shows results for the indirect scenario. In particular, there was a period of time in early September when the winds were persistently easterly, thereby driving the nearshore cells offshore at the surface (Figure 9) only to be replenished by new cells arriving along the bottom. Once advected offshore, these near surface particles (cells) were entrained in the (Loop Current-induced) southward-directed upwelling flow and advected around the Florida Keys.

\section{Summary and Conclusions}

The 2018 K. brevis HAB on the west coast of Florida was perhaps the worst red tide occurrence since 2005. We explain this as the confluence of cells remaining from the former 2017 bloom being reinforced to by a newly formed bloom in 2018. Such blooms are thought to initiate offshore at midshelf when the water conditions there are nutrient deplete (oligotrophic), allowing $\mathrm{K}$. brevis, through a complex sequence of events, to out-complete faster growing phytoplankton. The water conditions in which this may (or may not) occur are determined by the ocean circulation. If conducive for bloom development to occur, then there will likely be a major red tide event; if not conducive, then there likely will not be a major red tide event in any given year. The circulation was conducive in both 2017 and 2018, and hence, we experienced major red tides in each of these years continuing through January 2019. Hindcast analyses show that such hypothesis accounts for 20 out of 25 years for which simultaneous $K$. brevis and ocean circulation data exist. These conditions are determined by upwelling, a requirement for transporting new cells from their initiation region offshore to their manifestation region along the shoreline. The process is subtle, however, because too much upwelling in spring to early summer months, when new $K$. brevis blooms tend to form, will suppress such formation by the advection of new inorganic nutrients onto the shelf from the deeper ocean, thereby favoring faster growing, benign phytoplankton over the harmful $K$. brevis.

As a test for offshore initiation and confluence between blooms from two different years, a glider was deployed to map water properties offshore within the hypothesized formative region. As expected, 
relatively high chlorophyll and low oxygen levels were observed along the bottom at midshelf, along with an upwelling favorable circulation. Shortly thereafter, elevated levels of $K$. brevis were detected along the Pinellas County, FL, shoreline (just north of Tampa Bay). A Lagrangian trajectory analysis, using a numerical coastal ocean circulation model, demonstrated the connection (via upwelling) between the offshore generation region and the coastline manifestation region. Moreover, such analyses also accounted for the subsequent appearance of $K$. brevis red tide, both along Florida's Panhandle and east coasts. Advection to the Panhandle may be attributed to Tropical Storm Gordon, and advection to the east coast may be attributed to continued upwelling and subsequent transport around the Florida Keys and into the Gulf Stream. Once in the Gulf Stream, it is only a matter of days before cells can arrive at Palm Beach, Florida, where the 2018 bloom was first observed on the east coast, and points farther north. Thus, we can explain why 2018 was one of those rare years in which red tides of a common origin were simultaneously observed in all three of these regions: the west Florida epicenter from Tampa Bay to Charlotte Harbor, Florida's Panhandle coast, and Florida's east coast.

Further advances in our ability to forecast $K$. brevis blooms for Florida (and elsewhere) will require continued observations, particularly of water properties across the water column within the formative region. Repeated glider sections are an effective way of doing this, along with nutrient sensors mounted near bottom on strategically located moorings. From a biological perspective, missing are testable hypotheses on eventual bloom demise. Some of this may also be physical. If the convergence of cells both by a combination of advection and growth/mortality is positive, then a bloom will continue; if negative, then a bloom will abate. Only though well-conceived, interdisciplinary programs will answers to these and other questions of coastal ocean ecology be obtained.

\section{Acknowledgments}

Support was provided by the NOAA NCCOS PCM HAB Program (NA15NOS4780174), the NOAA IOOS SECOORA Program (NA16NOS0120028), and the NASA Ocean Biology and Biogeochemistry program (NNX14AL98G). Our Collaboration for Prediction of Red Tides (CPR) receives support from the University of South Florida, College of Marine Science. Support for FWWCFWRI's HAB monitoring and research program is provided by the State of Florida. Support specific to the glider deployment was from a State of Florida planning grant for a Gulf of Mexico Joint Institution at the University of South Florida. This work also benefited from the Extreme Science and Engineering Discovery Environment (XSEDE, Award OCE170007), which is supported by National Science Foundation grant ACI-1548562. This is CPR contribution 54 and PCMHAB contribution PCM50. The data used in this publication are available either upon request to the authors or through the following sites: (1) The trajectory and glider data are available at https:// usf.app.box.com/s/hqdiwv0y3wtq7oixw76pg98fowdnsvyl, 2) the $K$. brevis cell abundance data are available through the FWWC-FWRI HAB Monitoring Database (https://myfwc. com/research/redtide/monitoring/ database/), and (3) the satellite ocean color data and analyses are at USF website (https://optics.marine.usf.edu/ projects/iris.html).

\section{References}

Chassignet, E. P., Hurlburt, H. E., Metzger, E. J., Smedstad, O. M., Cummings, J., Halliwell, G. R., et al. (2009). U.S. GODAE: Global Ocean Prediction with the HYbrid Coordinate Ocean Model (HYCOM). Oceanography, 22, 48-59.

Chen, C. S., Liu, H., \& Beardsley, R. C. (2003). An unstructured, finite-volume, three-dimensional, primitive equation ocean model: Application to coastal ocean and estuaries. Journal of Atmospheric and Oceanic Technology, 20(1), 159-186. https://doi.org/10.1175/ 1520-0426(2003)020<0159:AUGFVT>2.0.CO;2

Heil, C. A. (1986). Vertical migration of the Florida red tide dinoflagellate, Ptychodiscus brevis, (MS thesis, p. 118). Florida: University of South Florida.

Heil, C. A., Dixon, L. K., Hall, E., Garrett, M., Lenes, J. M., O'Neil, B. M., et al. (2014). Blooms of Karenia brevis (Davis) G. Hansen \& O. Moestrup on the West Florida Shelf: Nutrient sources and potential management strategies based on a multi-year regional study. Harmful Algae, 38, 127-140. https://doi.org/10.1016/j.hal.2014.07.016

Hu, C., Barnes, B. B., Qi, L., Lembke, C., \& English, D. (2016). Vertical migration of Karenia brevis in the northeastern Gulf of Mexico observed from glider measurements. Harmful Algae, 58, 59-65. https://doi.org/10.1016/j.hal.2016.07.005

$\mathrm{Hu}, \mathrm{C} .$, \& Feng, L. (2016). Modified MODIS fluorescence line height data product to improve image interpretation for red tide monitoring in the eastern Gulf of Mexico. Journal of Applied Remote Sensing, 11(1). https://doi.org/10.1117/1.JRS.11.012003

Hu, C., Muller-Karger, F. E., \& Swarzenski, P. W. (2006). Hurricanes, submarine groundwater discharge, and Florida's red tides. Geophysical Research Letters, 33, L11601. https://doi.org/10.1029/2005GL025449

Kamykowski, D., Grabowski, K. M., Morrison, J. M., McCulloch, A. A., Nyadjro, E. S., Thomas, C. A., \& Sinclair, G. A. (2013). Cold front induced changes on the Florida panhandle shelf during October 2008. Continental Shelf Research, 54, 52-66. https://doi.org/10.1016/j. csr.2012.12.006

Lenes, J. M., Darrow, B. P., Cattrall, C., Heil, C. A., Vargo, G. A., Callahan, M., et al. (2001). Iron fertilization and Trichodesmium response on the West Florida shelf. Limnology and Oceanography, 46(6), 1261-1277. https://doi.org/10.4319/lo.2001.46.6.1261

Liu, Y., Weisberg, R. H., \& Lembke, C. (2015). Glider salinity correction for unpumped CTD sensors across a sharp thermocline. In Y. Liu, A. MacFadyen, Z.-G. Ji, \& R. H. Weisberg (Eds.), Coastal ocean observing systems (pp. 305-325). London, UK: Elsevier (Academic Press). https://doi.org/10.1016/B978-0-12-802022-7.00017-1

Liu, Y., Weisberg, R. H., Lenes, J., Zheng, L., Hubbard, K., \& Walsh, J. J. (2016). Offshore forcing on the West Florida shelf "pressure point" and its upwelling influence on harmful algal blooms. Journal of Geophysical Research: Oceans, 121, 5501-5515. https://doi.org/10.1002/ 2016JC011938Y

McCulloch, A. A., Kamykowski, D., Morrison, J. M., Thomas, C. J., \& Pridgen, K. G. (2013). A physical and biological context for Karenia brevis seed populations on the northwest Florida shelf during July 2009. Continental Shelf Research, 63, 94-111. https://doi.org/10.1016/ j.csr.2013.05.001

O'Neil, J. M., \& Heil, C. A. (Eds.) (2014). Nutrient dynamics of Karenia brevis red tide blooms in the eastern Gulf of Mexico. Harmful Algae, 38, 1-140. special issue

Rudnick, D. L., Davis, R. E., Eriksen, C. C., Fratantoni, D. M., \& Perry, M. J. (2004). Underwater gliders for ocean research. Marine Technology Society Journal, 38(2), 73-84. https://doi.org/10.4031/002533204787522703

Soto, I. M., Muller-Karger, F. E., Hu, C., \& Wolny, J. (2018). Characterization of Karenia brevis blooms on the West Florida Shelf using ocean color satellite imagery: Implications for bloom maintenance and evolution. Journal of Applied Remote Sensing, 11(1). https://doi.org/10.1117/1.JRS.11.012002

Steidinger, K. A. (1975). Implications of dinoflagellate life cycles on initiation of Gymnodinium breve red tides. Environmental Letters, 9(2), 129-139. https://doi.org/10.1080/00139307509435842 
Vargo, G. A., Heil, C. A., Fanning, K. A., Dixon, L. K., Neely, M. B., Lester, K., et al. (2008). Nutrient availability in support of Karenia brevis blooms on the central West Florida Shelf: What keeps Karenia blooming? Continental Shelf Research, 28(1), 73-98. https://doi.org/ 10.1016/j.csr.2007.04.008

Walsh, J. J., Jolliff, J., Darrow, B. P., Lenes, J. M., Milroy, S. P., Remsen, D., et al. (2006). Red tides in the Gulf of Mexico: Where, when, and why. Journal of Geophysical Research, 111, C11003. https://doi.org/10.1029/2004JC002813

Walsh, J. J., \& Kirkpatrick, G. (Eds.) (2008). Ecology and oceanography of Florida harmful algal blooms. Continental Shelf Research, 28(1), 1-2 (special issue). https://doi.org/10.1016/j.csr.2007.04.015

Walsh, J. J., Weisberg, R. H., Dieterle, D. A., He, R., Darrow, B. P., Jolliff, J. K., et al. (2003). Phytoplankton response to intrusions of slope water on the West Florida Shelf: Models and observations. Journal of Geophysical Research, 108(C6), 3190. https://doi.org/10.1029/ 2002JC001406

Walsh, J. J., Weisberg, R. H., Lenes, J. M., Chen, F. R., Dieterle, D. A., Zheng, L., et al. (2009). Isotopic evidence for dead fish maintenance of Florida red tides, with implications for coastal fisheries over both source regions of the West Florida Shelf and within downstream waters of the South Atlantic Bight. Progress in Oceanography, 80(1-2), 51-73. https://doi.org/10.1016/j.pocean.2008.12.005

Weisberg, R. H., Barth, A., Alvera-Azcárate, A., \& Zheng, L. (2009). A coordinated coastal ocean observing and modeling system for the West Florida Shelf. Harmful Algae, 8(4), 585-597. https://doi.org/10.1016/j.hal.2008.11.003

Weisberg, R. H., \& He, R. (2003). Local and deep-ocean forcing contributions to anomalous water properties on the West Florida Shelf. Journal of Geophysical Research, 108(C6), 3184. https://doi.org/10.1029/2002JC001407

Weisberg, R. H., Zheng, L., Liu, Y., Corcoran, A., Lembke, C., Hu, C., et al. (2016). Karenia brevis blooms on the West Florida shelf: A comparative study of the robust 2012 bloom and the nearly null 2013 event. Continental Shelf Research, 120, 106-121. https://doi.org/ 10.1016/j.csr.2016.03.011

Weisberg, R. H., Zheng, L., Liu, Y., Lembke, C., Lenes, J. M., \& Walsh, J. J. (2014). Why a red tide was not observed on the West Florida continental shelf in 2010. Harmful Algae, 38, 119-126. https://doi.org/10.1016/j.hal.2014.04.010

Weisberg, R. H., Zheng, L., Liu, Y., Murawski, S., Hu, C., \& Paul, J. (2016). Did Deepwater horizon hydrocarbons transit to the West Florida continental shelf? Deep Sea Research Part II: Topical Studies in Oceanography, 129, 259-272. https://doi.org/10.1016/j.dsr2.2014.02.002

Weisberg, R. H., Zheng, L., \& Peebles, E. (2014). Gag grouper larvae pathways on the West Florida shelf. Continental Shelf Research, 88, 11-23. https://doi.org/10.1016/j.csr.2014.06.003

Weisberg, R. H., Zheng, L. Y., \& Liu, Y. (2016). West Florida shelf upwelling: Origins and pathways. Journal of Geophysical Research: Oceans, 121, 5672-5681. https://doi.org/10.1002/2015JC011384

Weisberg, R. H., Zheng, L., \& Liu, Y. (2017). On the Movement of Deepwater Horizon Oil to Northern Gulf Beaches. Ocean Modelling, 111 , 81-97. https://doi.org/10.1016/j.ocemod.2017.02.002

Zheng, L., \& Weisberg, R. H. (2012). Modeling the West Florida Coastal Ocean by downscaling from the Deep Ocean, across the continental shelf and into the estuaries. Ocean Model, 48, 10-29. https://doi.org/10.1016/j.ocemod.2012.02.002 